\title{
MRI findings in Collet-Sicard syndrome
}

Figure Imaging findings in Collet-Sicard syndrome

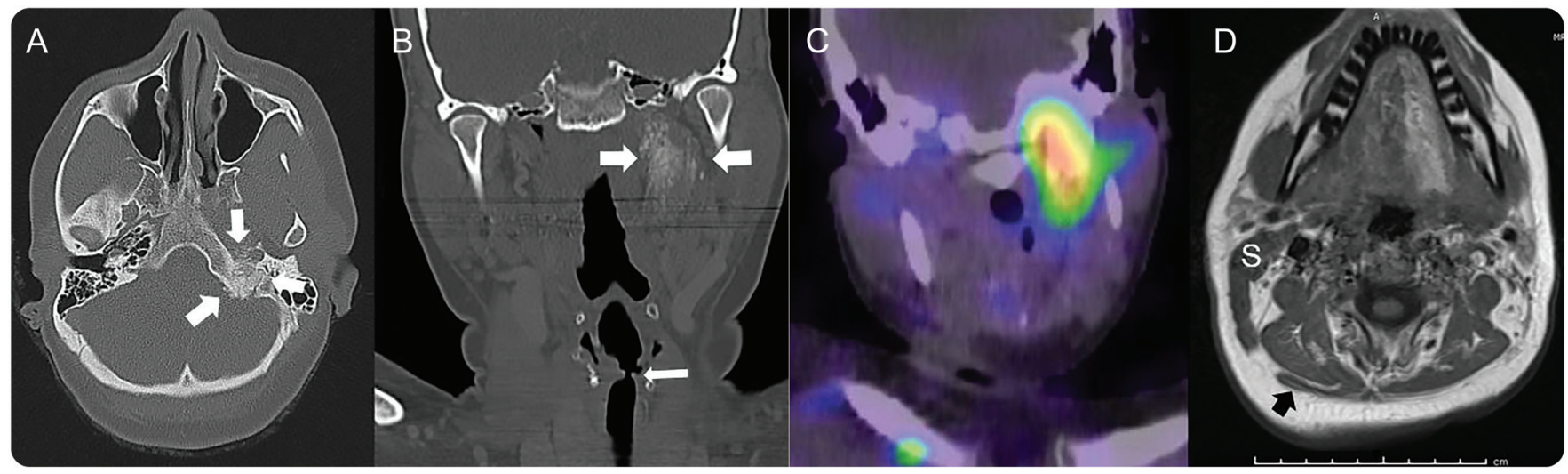

(A) Axial skull base CT: calcified mass obliterating left jugular foramen. (B) Coronal neck CT: partially calcified parapharyngeal mass; paralyzed left vocal cord. (C) 18-Fluorodeoxyglucose PET: torticollis; avid glomus tumor uptake. (D) T1-weighted MRI: fatty degeneration-related left tongue hyperintensity. Leftsided sternocleidomastoid and trapezius atrophy (S + arrowhead = nonatrophied muscles).

A 44-year-old woman presented with 4 weeks of increasing neck pain and newly arising dysphagia and hoarseness. Examination was remarkable for left tongue atrophy and fibrillations, tongue deviation to the left, left vocal cord paralysis, and trapezius and sternocleidomastoid muscle wasting (figure) (Collet-Sicard syndrome, CN IX-CNXII paralysis ${ }^{1,2}$ ). Workup revealed a partially calcified left cervical glomus jugulare tumor extending from the jugular foramen into the parapharyngeal space (figure, A). The tumor encased the left internal carotid artery, CNXI, and CNXII. The inoperable lesion was treated with external beam radiation therapy (45 Gy, 25 fractions). Her neurologic syndrome remains stable with improved pain.

Frank J. Barbiero, Joachim M. Baehring, MD, DSc, Robert K. Fulbright, MD, Kevin P. Becker, MD, PhD From the Yale School of Medicine, New Haven, CT.

Author contributions: Frank J. Barbiero: analysis and interpretation of data, drafting and revising of manuscript. Joachim M. Baehring: analysis and interpretation of data, drafting and revising of manuscript. Robert K. Fulbright: analysis and interpretation of data, revising of manuscript. Kevin P. Becker: analysis and interpretation of data, revising of manuscript.

Study funding: No targeted funding reported.

Disclosure: The authors report no disclosures relevant to the manuscript. Go to Neurology.org for full disclosures

Correspondence to Dr. Barbiero: frank.barbiero@yale.edu

1. Collet FJ. Sur un nouveau syndrome paralytique pharyngo-larynge par blessure de guerre (hemiplegie glosso-laryngo-scapulopharyngee). Lyon Med 1915;124:121-129.

2. Sicard JA. Syndrome du carrefour condylodechire posterieur (type pur de paralysie des quatre derniers nerfs craniens). Marseille Med 1917;53:385-397. 


\title{
Neurology
}

\author{
MRI findings in Collet-Sicard syndrome \\ Frank J. Barbiero, Joachim M. Baehring, Robert K. Fulbright, et al. \\ Neurology 2017;88;811 \\ DOI 10.1212/WNL.0000000000003643
}

This information is current as of February 20, 2017

\section{Updated Information \& Services}

\section{References}

Subspecialty Collections

\section{Permissions \& Licensing}

Reprints including high resolution figures, can be found at: http://n.neurology.org/content/88/8/811.full

This article cites 2 articles, 0 of which you can access for free at: http://n.neurology.org/content/88/8/811.full\#ref-list-1

This article, along with others on similar topics, appears in the following collection(s):

\section{All Oncology}

http://n.neurology.org/cgi/collection/all_oncology

Clinical neurology examination

http://n.neurology.org/cgi/collection/clinical_neurology_examination Cranial neuropathy

http://n.neurology.org/cgi/collection/cranial_neuropathy

\section{MRI}

http://n.neurology.org/cgi/collection/mri

PET

http://n.neurology.org/cgi/collection/pet

Information about reproducing this article in parts (figures,tables) or in its entirety can be found online at:

http://www.neurology.org/about/about_the_journal\#permissions

Information about ordering reprints can be found online:

http://n.neurology.org/subscribers/advertise

Neurology ${ }^{\circledR}$ is the official journal of the American Academy of Neurology. Published continuously since 1951, it is now a weekly with 48 issues per year. Copyright @ 2017 American Academy of Neurology. All rights reserved. Print ISSN: 0028-3878. Online ISSN: 1526-632X.

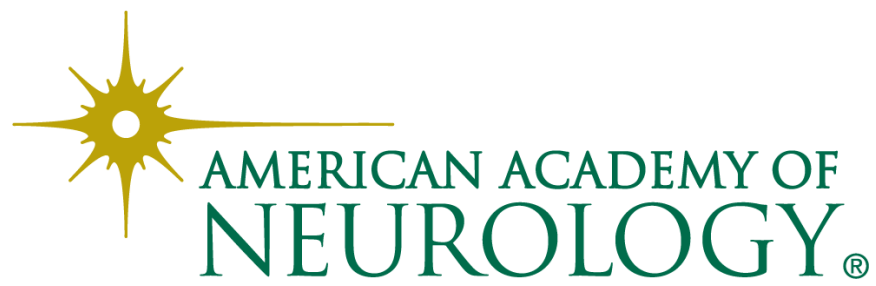

